\section{International Journal of

DOI: 10.31695/IJASRE.2019.33296

\title{
Morphometric Analysis of the southern Al Jabal Al Akhdar Watersheds NE Libya
}

\author{
Salah Hamad
}

Lecturer

\begin{abstract}
Department of Natural Resources, Faculty of the Natural Resources and Environment sciences
University of Omar Al Mukhtar

Al Baydah, Al Jabal Al Akhdar
\end{abstract}

Libya

\begin{abstract}
The study aimed to quantify the morphometric characteristics of 11 watersheds in south Al Jabal Al Akhdar area (Green Mountain) located on northeast Libya. Where Digital Elevation Model (DEM) data of 1 arcsec resolution for the study area downloaded from USGS Earth Explorer and processed to extract the watershed attributes using ArcGIS software. In addition, the linear, areal, and relief aspects parameters and indices were computed. The stream number for the watersheds varies from first orders to seventh orders, where a large number of streams was found in the first, second, and third orders. Drainage networks of the watersheds are a dendritic pattern reflects the subsurface lithology. The total lengths of streams in the study area are 35757.8 $\mathrm{km}$. Also, the correlation coefficients which calculated for the relationship between the stream number and the stream count and lengths showed strong inverse relation.Moreover, observed bifurcation ratio for the watersheds considered as low with exception of the seventh order in some watersheds, where the streams tend to be braided due to the stream runoff through the depositional zone that consisting of recent uncompacted fluvial deposits. Drainage densities in the study area are coarse which indicated the much susceptibility to flooding and soil erosion. Where the drainage texture in the study area mostly is very coarse with the exception of some watersheds those are considered as coarse texture. Stream frequencies show very low values. Furthermore, the length of overland flow classified as moderate. The results of relief aspects computation show variation among the watersheds from high to low values. For the ruggedness number values, all watersheds show sharp morphology. Finally, The morphometric characteristics of the watersheds show moderate geomorphologic characteristics, stability in tectonic geology, and homogenous lithology, also the watersheds have intermediate to low flooding susceptibility but in case of heavy rainstorms a very strong flash flood may occur as the upper stream areas of the watersheds prevail high risk of soil erosion, therefore flood protection, and soil conservation measures are crucially demanded in the study area especially in the northern parts.
\end{abstract}

Key Words: Green Mountain, Morphometry, GIS, Hydrology, Water harvesting.

\section{INTRODUCTION}

Morphometric analysis plays a significant role in understanding the geohydrological characteristics of the drainage basin in relation to the terrain feature and its flow patterns. It also helps to estimate the incidence of infiltration and runoff and another related hydrological character of a watershed like erosion and sediment transport which has a strong implication for natural resource conservation[1].Moreover Drainage basin watershed analysis based on morphometric parameters is very important for watershed planning since it gives an idea about the basin characteristics regarding slope, topography, soil condition, runoff characteristics, surface water potential, etc.[2].The study area is shown in figure (1) located on the southern $\mathrm{Al} \mathrm{Jabal} \mathrm{Al} \mathrm{Akhdar}$ area (Green Mountain), which is a mountain range along the northern coast of north eastern Libya, located approximately $31^{\circ} \mathrm{N}$ ,and $23^{\circ} \mathrm{E}$. The areal extent of the study area about $17721 \mathrm{~km}^{2}$ extending from Wadi $\mathrm{Al} \mathrm{Bab}$ in the west to Wadi Tamimi in the east ,and from Taknis and Sidi Al Humree villages in the north to the temporary lakes areas in the south. Altitude of the watershed ranges from $-2 \mathrm{~m}$ in the southern eastern parts to $880 \mathrm{~m}$ in the northern part. Moreover the study area comes under the agroclimatic zone of $\mathrm{Al} \mathrm{Jabal} \mathrm{Al} \mathrm{Akhdar} \mathrm{which} \mathrm{is} \mathrm{a} \mathrm{hot} \mathrm{arid} \mathrm{ecological} \mathrm{region} \mathrm{that} \mathrm{characterized} \mathrm{by} \mathrm{a} \mathrm{hot} \mathrm{summer} \mathrm{and} \mathrm{dry} \mathrm{winter} \mathrm{in}$ the south, and semi-arid in the north. The dominant land cover in the study area consists alluvial plains composed of ancient sediments of the fluvial activities and spreading zones composed of recent fluvial deposits ,and both are consist of deposits range 
from coarse desert alluvium with a pavement of gravel on the surface to silty alluvium with a finely textured surface. Vegetation land cover that consists of the forest land distributed only in northern parts of the study area consists of some species like cypress (Cupressus spp.) pinus (halepensis spp.), ilex (Ilex spp.), juniper (Juniperus spp.) and other trees. Grassland and steppes landcover consists of plant communities of dwarf shrubs or grasses and annual herbs distributed sparsely in all the study area. The bare rock landcover which is consolidated and non-consolidated consisting mainly of marine carbonate rocks ranging in age from late Cretaceous to Quaternary.

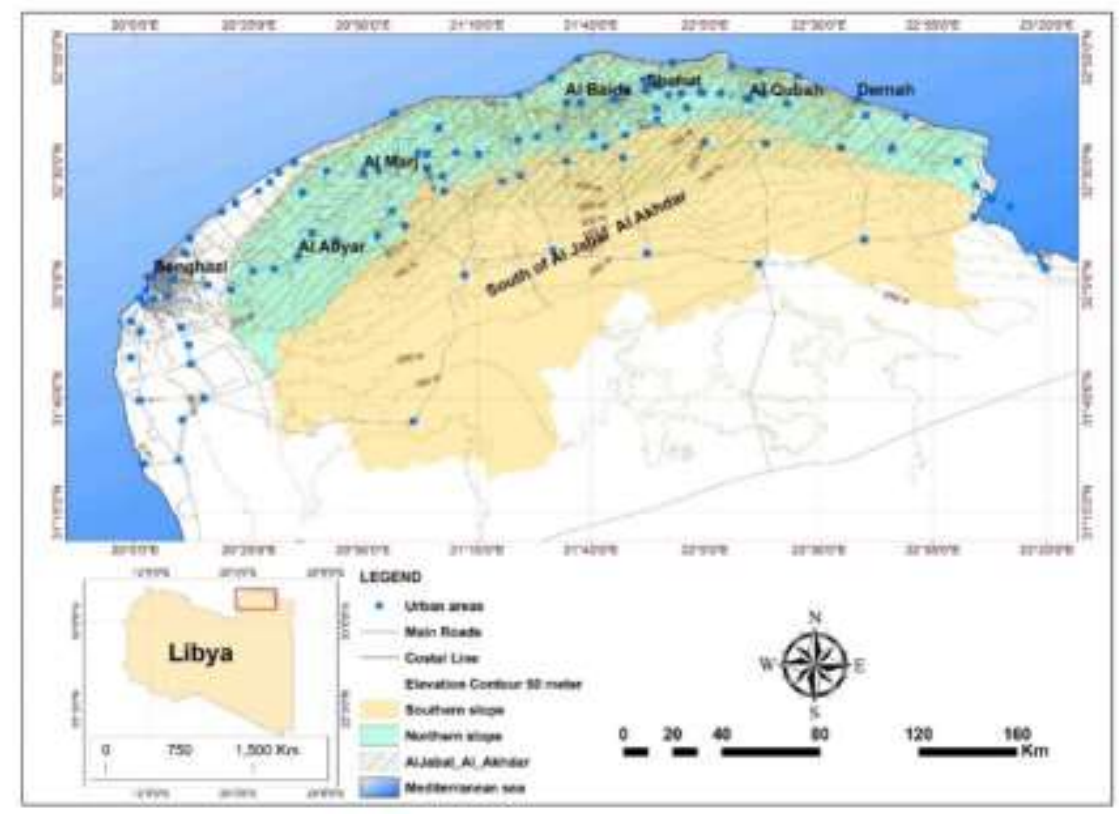

Figure 1. Location map of the study area

The watersheds are large and have a moderate slope receive a considerable amount of precipitation especially in the northern parts which reach $300 \mathrm{~mm}$ per year ,but unfortunately not utilized in a proper way, where most of the precipitated rain is lost in the evaporation and the remain goes for sudden floods that occur annually leading to natural disasters that result in heavy human and economic losses, in addition to the problems caused by soil erosion and transport from the north to the south leading to the loss of vegetation cover. Since soil and water resource are main resources in semi-arid and arid regions, therefore the aim of this work is to quantify the morphometric characteristics by conducting an automatic extraction of streams and morphometric parameters and indices using GIS techniques and remote sensing data for the southern Al Jabal Al Akhadar watersheds to provide reconnaissance data to help water and soil conservation issues.

\section{RESESRCH METHODOLOGY}

Digital Elevation Model (DEM) data of 1 arcsec resolution for the study area downloaded from USGS Earth explorer and processed according to the steps in figure (3) using ArcGIS software hydrology toolset, which is a tool in ESRI ArcGIS Spatial Analyst extension for processing topographic data to identify sinks, determine flow direction, calculate flow accumulation, delineate watersheds, create stream networks, and perform morphometric and hydrologic analysis[3]. Stream order was made according to Strahler's law, and the morphometric parameters and indices were calculated according to the formulas in table (1).

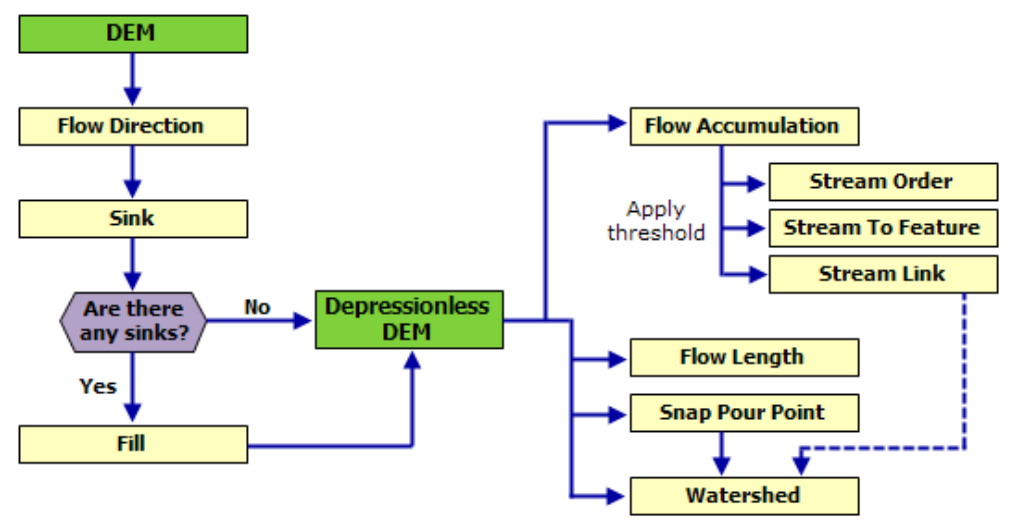

Figure 2. Watershed attribute extraction steps (ESRI,2018) 
Table 1 . Methods for Calculation of Morphometric Parameters

\begin{tabular}{|c|c|c|c|c|}
\hline Parameter & Symbo & Unit & Formulas & Citation \\
\hline \multicolumn{5}{|l|}{ Linear Aspects } \\
\hline Stream Order & $\mathrm{u}$ & - & Hierarchical rank & [4] \\
\hline No.of stream & $\mathrm{Nu}$ & - & & [5] \\
\hline Stream Length & $\mathrm{Lu}$ & $\mathrm{km}$ & $\mathrm{L}_{\mathrm{u}}=\mathrm{L}_{1}+\mathrm{L}_{2} \ldots \ldots \ldots . \mathrm{L}_{\mathrm{n}}$ & [6] \\
\hline Mean Stream Length & Lsm & $\mathrm{km}$ & $\mathrm{L}_{\mathrm{sm}}=\mathrm{L}_{\mathrm{u}} / \mathrm{N}_{\mathrm{u}}$ & [6] \\
\hline Stream length ratio & $\mathrm{R}_{\mathrm{L}}$ & - & $\begin{array}{l}\text { Where } \mathrm{L}_{\mathrm{u}}=\text { The mean length of all stream segments of a } \\
\text { given order }(u) \mathrm{L}(u-1)=\text { The mean length of all stream } \\
\text { segments of one order less to given order }(\mathrm{u})\end{array}$ & [5] \\
\hline Bifurcation ratio & $\mathrm{R}_{\mathrm{b}}$ & - & $\begin{array}{l}\mathrm{Rb}=\mathrm{Nu} / \mathrm{Nu}+1 \\
R b=N u / N u+1 ; \text { Where, } N u=\text { Total no. of stream } \\
\text { segments of order " } u \text { "; } N u+1=\text { Number of stream } \\
\text { segments of the next higher order }\end{array}$ & [7] \\
\hline Mean Bifurcation ratio & $\mathrm{R}_{\mathrm{bm}}$ & - & average of bifurcation ratio of all orders & [4] \\
\hline \multicolumn{5}{|l|}{ Areal Aspects } \\
\hline Basin length & $\mathrm{L}_{\mathrm{b}}$ & $\mathrm{km}$ & Calculated by ArcGIS software & [5] \\
\hline Basin area & A & $\mathrm{km}^{2}$ & Calculated by ArcGIS software & [5] \\
\hline Basin Perimeter & $\mathrm{P}$ & $\mathrm{km}$ & Calculated by ArcGIS software & [5] \\
\hline Drainage Density & Dd & $\mathrm{Km} / \mathrm{km}^{2}$ & $\mathrm{Dd}=\mathrm{Lu} / \mathrm{A}$ & [5] \\
\hline Drainage texture & Dt & $1 / \mathrm{km}$ & $\mathrm{Dt}=\mathrm{Nu} / \mathrm{P}$, Where $\mathrm{P}=$ Perimeter $(\mathrm{km})$ & [5] \\
\hline Stream Frequency & Fs & $1 / \mathrm{km}^{2}$ & $\mathrm{Fs}=\mathrm{Nu} / \mathrm{A}$ & [5] \\
\hline Form Factor & $\mathrm{Rf}$ & - & $\mathrm{Rf}=\mathrm{A} / \mathrm{Lb}^{2}$ Where, $\mathrm{Lb}^{2}=$ Square of the basin length & [5] \\
\hline Elongation Ratio & $\operatorname{Re}$ & - & $\mathrm{Rc}=4 \pi \mathrm{A} / \mathrm{P}^{2}$ & [6] \\
\hline Circulatory Ratio & Rc & - & $\operatorname{Re}=\left(2 / \mathrm{L}_{\mathrm{b}}\right) *(\mathrm{~A} / \pi)^{0.5}$ & {$[8]+[4]$} \\
\hline Length of Overland flow & Lof & $\mathrm{Km}^{2} / \mathrm{km}$ & Lof $=1 / 2 \mathrm{Dd}$ & [5] \\
\hline \multicolumn{5}{|l|}{ Relief Aspects } \\
\hline Basin Relief & $\mathrm{Bh}$ & $\mathrm{m}$ & $\mathrm{Bh}=$ Max. - Min. elevation of watershed & [9] \\
\hline Relief ratio & $\mathrm{Rh}$ & $\mathrm{m} / \mathrm{km}$ & $\mathrm{Rh}=\mathrm{Bh} / \mathrm{L}_{\mathrm{b}}$ & [6] \\
\hline Ruggedness number & $\mathrm{Rn}$ & $\mathrm{m} * \mathrm{Km} / \mathrm{km}^{2}$ & $\mathrm{Rn}=\mathrm{Bh}^{*} \mathrm{Dd}$ & [6] \\
\hline
\end{tabular}

\section{RESULT AND DISCUSSION}

\subsection{Spatial characteristics}

Digital Elevation Model (DEM) processed and the results area illustrated in figure (3) and the geometric variables in the table (2), where the overall areas of southern watersheds of Al Jabal Al Akhdar 17721 a square kilometer, these watersheds bounded in the north by the hydrologic divide that extends from the southwest to the east with the length of $470,75 \mathrm{~km}$.

\subsection{Linear Aspects}

The stream number or stream ordering (u) refers to the categorized position of the stream in a drainage basin. The value of stream order is dimensionless and it has a direct relation with the area of the subsidizing watershed, channel dimension as well as the stream discharges [10]. In the study area the streams orders and their numbers were extracted using ArcGIS hydrology toolset as in table (3), and the linear aspects were computed according to the formulas in table (1), The result of linear aspects computation are shown in the tables (4),(5), (6), and (7). The stream order $(\mathrm{Nu})$ of the watersheds varies from first orders to seventh orders, where the total number of streams $(\mathrm{Nu})$ for the watersheds is 53562 . Where large numbers of streams were found in the first, second, and third orders, furthermore the first order streams account for $50 \%$ of the total number of streams in all watersheds. moreover, it is observed the stream order increases as the count of streams decrease with exception of Al Bab watershed that shows low stream segments in the second order, which may due to the effect of local tectonic control. The drainage maps of each watershed with a stream order for the study area are shown in the figures (4) and (5), where the drainage networks of the watersheds are a dendritic pattern reflects the homogeneity in the subsurface lithology. 


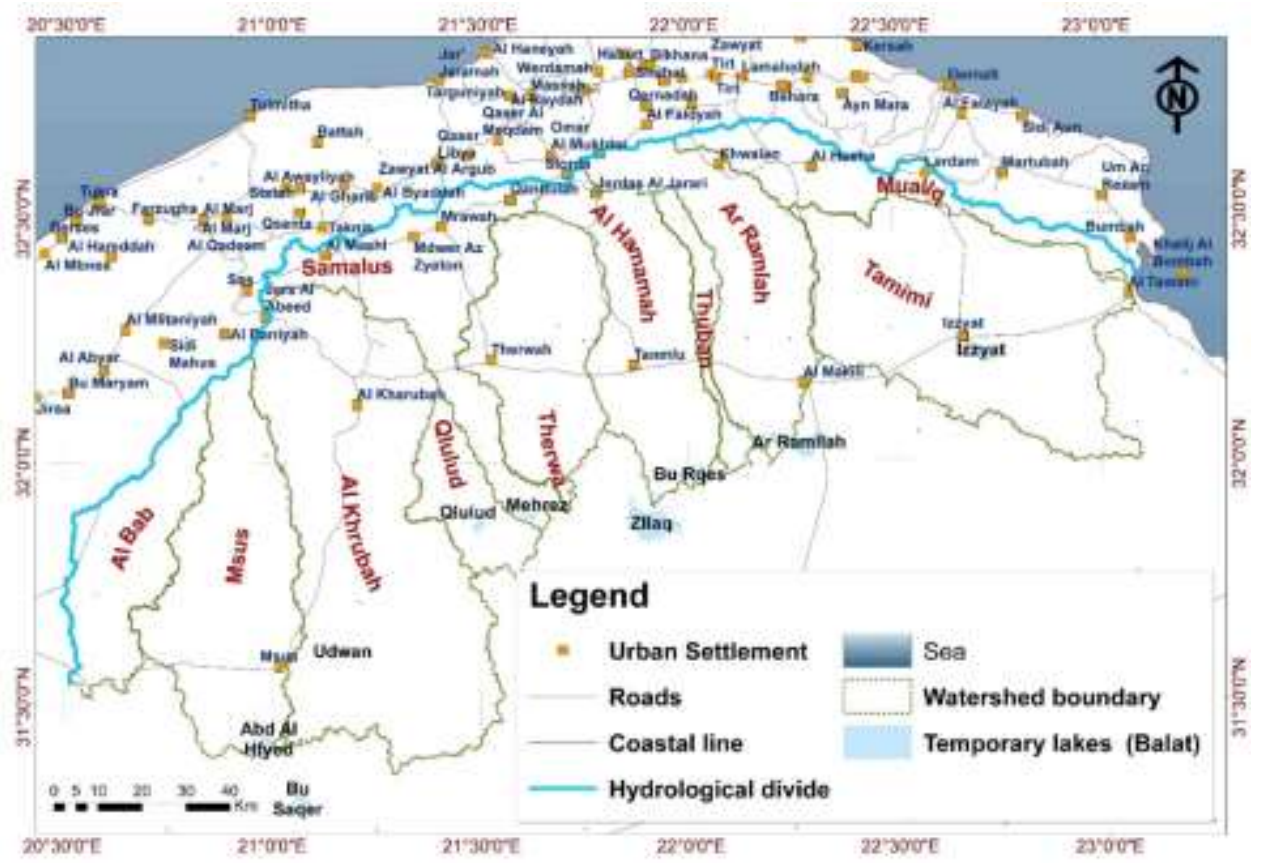

Figure 3. Spatial characteristics of the study area

Table 2.Geometric variables of the southern Al Jabal Al Akhadar Watersheds

\begin{tabular}{|c|c|c|c|c|c|c|c|c|}
\hline Watershed & 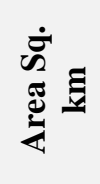 & 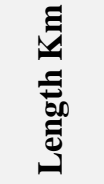 & 离 & Z光旁 & 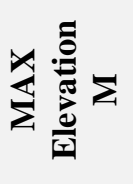 & 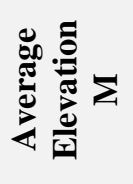 & 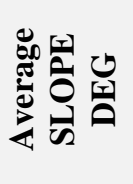 & 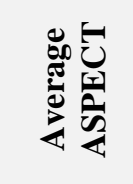 \\
\hline Al Bab & 1082 & 74.1 & 332.3 & 98 & 603 & 276 & 3.41 & SE (157) \\
\hline Msus & 2039 & 90.9 & 416.3 & 44 & 644 & 212 & 2.53 & SE (134) \\
\hline Al Khrubah & 3928 & 105.8 & 599.8 & 63 & 670 & 222 & 2.36 & SE (124) \\
\hline Samalus & 1511 & 87.7 & 512.7 & 139 & 775 & 419 & 3.61 & SE (149) \\
\hline Qlulud & 569 & 45.8 & 216.9 & 140 & 303 & 188 & 2.21 & SE (119) \\
\hline Therwa & 1484 & 67.5 & 309.9 & 141 & 736 & 364 & 3.72 & SE (151) \\
\hline Al Hamamah & 1522 & 78.9 & 354.9 & 124 & 832 & 364 & 3.69 & SE (149) \\
\hline Tanmlou & 301 & 65.8 & 251.3 & 125 & 762 & 382 & 3.86 & SE (148) \\
\hline ArRamlah & 1559 & 81.7 & 364.9 & 131 & 880 & 427 & 3.16 & SE (140) \\
\hline Muallq & 869 & 109.1 & 426.8 & -6 & 852 & 417 & 3.34 & E (106) \\
\hline Tamimi & 2857 & 79.9 & 491.3 & -2 & 464 & 220 & 2.25 & $\mathrm{E}(112)$ \\
\hline
\end{tabular}

Stream length $(\mathrm{Lu})$ which is a characteristic property related to drainage network [6],in the study area the highest lengths observed in the first orders and decreases as the stream order increases, where the total lengths of streams in the study area are $35757.8 \mathrm{~km}$.Also, the first order streams account for $50 \%$ of the stream length in all watersheds, where Al Kharubah and Msus watersheds are the highest in stream lengths, and the lowest in stream lengths in Qlulud and Thuban watersheds.Fruthermore, the correlation coefficients calculated for the relation between the stream order versus the stream count and stream lengths showed strong inverse relation. Stream length (Lu) which is a characteristic property related to drainage network [6], in the study area the highest lengths observed in the first orders and decreases as the stream order increases, where the total lengths of streams in the study area are $35757.8 \mathrm{~km}$. Also, the first order streams account for $50 \%$ of the stream length in all watersheds, where $\mathrm{Al}$ Kharubah and Msus watersheds are the highest stream lengths and the lowest in stream lengths in Qlulud and Thuban watersheds. Furthermore, the correlation coefficients calculated for the relation between the stream order versus the stream count and stream lengths showed strong inverse relation. Stream length ratio $\left(\mathrm{R}_{\mathrm{L}}\right)$ which is defined as the ratio between the mean stream lengths of one order with that of the next lower order of the stream segments [11].The maximum value of $\mathrm{R}_{\mathrm{L}}$ in Tamimi watershed 6.714 watershed and minimum value also observed in Tamimi watershed, where the value of $R_{L}$ will have close resemblance with the 
comparative permeability of the underlying rock structures of the watershed. The $\mathrm{R}_{\mathrm{L}}$ values show significant interrelationship towards the discharge of streamflow on the surface and the stage of erosion of the watershed [12], moreover, the variation in the $\mathrm{R}_{\mathrm{L}}$ values from one order to the successive order reveals their delayed youthful stage in the development of geomorphic structures [13]. In the other hand, an increasing trend in the stream length ratio from lower order to higher order indicates their mature geomorphic stage[14].

Table 3. Total Number of stream segments

\begin{tabular}{|c|c|c|c|c|c|c|c|c|c|}
\hline & \multicolumn{7}{|c|}{ Orders } & \multirow{2}{*}{$\begin{array}{l}\text { Total } \\
(\mathrm{Nu})\end{array}$} & \multirow{2}{*}{$\begin{array}{l}\text { Correlation } \\
\text { coefficient }\end{array}$} \\
\hline Watershed & I & II & III & IV & $\mathbf{V}$ & VI & VII & & \\
\hline Al Bab & 1622 & 731 & 449 & 174 & 176 & 67 & 0 & 3219 & -0.874 \\
\hline Msus & 3182 & 1358 & 848 & 547 & 246 & 126 & 14 & 6321 & -0.875 \\
\hline AlKhrubah & 6088 & 2760 & 1481 & 1010 & 491 & 145 & 144 & 12119 & -0.871 \\
\hline Samalus & 2370 & 1087 & 633 & 345 & 123 & 159 & 0 & 4717 & -0.875 \\
\hline Qlulud & 889 & 421 & 205 & 130 & 82 & 27 & 0 & 1754 & -0.877 \\
\hline Therwa & 2281 & 1048 & 511 & 305 & 216 & 154 & 24 & 4539 & -0.860 \\
\hline Al Hamamah & 2385 & 1031 & 544 & 399 & 252 & 128 & 9 & 4748 & -0.864 \\
\hline Thuban & 457 & 199 & 127 & 31 & 88 & 0 & 0 & 902 & -0.862 \\
\hline Ar Ramlah & 2406 & 1018 & 679 & 274 & 173 & 264 & 110 & 4924 & -0.840 \\
\hline Muallq & 1334 & 587 & 284 & 217 & 62 & 161 & 0 & 2645 & -0.847 \\
\hline Tamimi & 3262 & 1993 & 1122 & 755 & 214 & 255 & 73 & 7674 & -0.923 \\
\hline
\end{tabular}

Table 4. Stream Length(Lu) km

\begin{tabular}{|c|c|c|c|c|c|c|c|c|c|}
\hline & \multicolumn{7}{|c|}{ Orders } & \multirow{2}{*}{ Total } & \multirow{2}{*}{$\begin{array}{c}\text { Correlation } \\
\text { coefficient }\end{array}$} \\
\hline Watershed & I & II & III & IV & $\mathbf{V}$ & VI & VII & & \\
\hline Al Bab & 993.3 & 47.0 & 271.1 & 102.2 & 92.3 & 32.0 & 0.0 & 1537.9 & -0.697 \\
\hline Msus & 2032.9 & 956.0 & 552.3 & 312.0 & 144.0 & 77.0 & 9.5 & 4083.7 & -0.905 \\
\hline AlKhrubah & 3836.8 & 1991.0 & 1017.0 & 653.0 & 312.0 & 86.0 & 87.0 & 7982.8 & -0.919 \\
\hline Samalus & 1398.0 & 682.8 & 362.5 & 180.5 & 54.0 & 86.0 & 0.0 & 2763.8 & -0.897 \\
\hline Qlulud & 553.0 & 292.0 & 147.0 & 87.0 & 47.0 & 24.0 & 0.0 & 1150.0 & -0.913 \\
\hline Therwa & 1437.0 & 729.0 & 335.0 & 161.0 & 120.0 & 96.0 & 13.0 & 2891.0 & -0.887 \\
\hline Al Hamamah & 1425.0 & 689.0 & 340.0 & 220.0 & 156.0 & 74.0 & 10.0 & 2914.0 & -0.891 \\
\hline Thuban & 278 & 140 & 85 & 18.6 & 51 & 0 & 0 & 572.6 & -0.900 \\
\hline Ar Ramlah & 1530 & 686 & 383 & 167 & 95 & 118 & 11 & 2990.0 & -0.874 \\
\hline Muallq & 801 & 409 & 170 & 130 & 34 & 87 & 0 & 1631.0 & -0.873 \\
\hline Tamimi & 4475 & 1493 & 699 & 441 & 10 & 80 & 43 & 7241.0 & -0.843 \\
\hline
\end{tabular}

Table 5. Mean Stream Length

\begin{tabular}{|c|c|c|c|c|c|c|c|}
\hline & \multicolumn{7}{|c|}{ Orders } \\
\hline Watershed & I & II & III & IV & V & VI & VII \\
\hline Al Bab & 0.612 & 0.064 & 0.604 & 0.588 & 0.525 & 0.478 & 0.000 \\
\hline Msus & 0.639 & 0.704 & 0.651 & 0.570 & 0.585 & 0.611 & 0.679 \\
\hline AlKhrubah & 0.630 & 0.721 & 0.687 & 0.647 & 0.635 & 0.593 & 0.604 \\
\hline Samalus & 0.590 & 0.628 & 0.573 & 0.523 & 0.439 & 0.541 & 0.000 \\
\hline Qlulud & 0.622 & 0.694 & 0.717 & 0.669 & 0.573 & 0.889 & 0.000 \\
\hline Therwa & 0.630 & 0.696 & 0.656 & 0.528 & 0.556 & 0.623 & 0.542 \\
\hline Al Hamamah & 0.597 & 0.668 & 0.625 & 0.551 & 0.619 & 0.578 & 9.000 \\
\hline Thuban & 0.608 & 0.704 & 0.669 & 0.601 & 0.580 & 0.000 & 0.000 \\
\hline Ar Ramlah & 0.636 & 0.674 & 0.564 & 0.609 & 0.549 & 0.447 & 0.100 \\
\hline Muallq & 0.600 & 0.697 & 0.599 & 0.599 & 0.548 & 0.540 & 0.000 \\
\hline Tamimi & 1.372 & 0.749 & 0.623 & 0.584 & 0.047 & 0.314 & 0.589 \\
\hline
\end{tabular}


International Journal of Advances in Scientific Research and Engineering (ijasre), Vol 5 (7), July-2019

Table 6.Stream length ratio

\begin{tabular}{|c|c|c|c|c|c|c|}
\hline & I/II & III/II & IV/III & V/IV & VI/V & VII/VI \\
\hline Al Bab & 0.105 & 9.389 & 0.973 & 0.893 & 0.910 & - \\
\hline Msus & 1.102 & 0.925 & 0.876 & 1.026 & 1.044 & 1.110 \\
\hline AlKhrubah & 1.145 & 0.952 & 0.942 & 0.983 & 0.933 & 1.019 \\
\hline Samalus & 1.065 & 0.912 & 0.913 & 0.839 & 1.232 & - \\
\hline Qlulud & 1.115 & 1.034 & 0.933 & 0.856 & 1.551 & - \\
\hline Therwa & 1.104 & 0.942 & 0.805 & 1.052 & 1.122 & 0.869 \\
\hline Al Hamamah & 1.118 & 0.935 & 0.882 & 1.123 & 0.934 & 1.922 \\
\hline Tanmlou & 1.157 & 0.951 & 0.898 & 0.964 & - & - \\
\hline Ar Ramlah & 1.060 & 0.837 & 1.081 & 0.901 & 0.814 & 0.224 \\
\hline Muallq & 1.160 & 0.859 & 1.001 & 0.915 & 0.985 & - \\
\hline Tamimi & 0.546 & 0.832 & 0.938 & 0.080 & 6.714 & 1.878 \\
\hline
\end{tabular}

Bifurcation ratio $R_{b}$ has a close relationship with the drainage network branching pattern as greater $R_{b}$, the lower the branching pattern in the drainage network and vice versa [15]. The higher value of $R_{b}$ shows the extreme overland flow and high tectonic activity. The lower value of $R_{b}$ shows very less distort of geological structure in the drainage pattern that evidently reflects the very partially disturbed watershed [16]. In addition, $\mathrm{R}_{\mathrm{b}}$ has a direct relationship with erodibility which makes the sub-watersheds having higher $\mathrm{R}_{\mathrm{b}}$ highly vulnerable for soil erosion. Various morphological parameters such as basin shape, drainage density, stream entrance angles, geological characteristics, and basin area also control $R_{b}$ [17],[18],[19] and [10]. Also, the classifications of range value for the $\mathrm{R}_{\mathrm{b}}$ varies among the researchers and there is no statement for it, therefore based on some researches, it can be concluded that less than five (5) may be classified into low, and more than five (5) into high [2].In the study area the bifurcation ratio is considered as low with the exception of the seventh order in Msus, Therwa, and Al Hamamah watersheds, where the $R_{b}$ values are high, which can be interpreted as the behavior of the streams tends to be braided due to the runoff through the depositional zone consist of a recent uncompacted fluvial sediments.

Table 7. Bifurcation ratio

\begin{tabular}{|c|c|c|c|c|c|c|c|}
\hline \multirow[b]{2}{*}{ Watershed } & \multicolumn{6}{|c|}{ Orders } & \multirow{2}{*}{ Mean } \\
\hline & I & II & III & IV & $\mathbf{V}$ & VI & \\
\hline Al Bab & 2.22 & 1.63 & 3.1 & 0.99 & 2.63 & - & 2.01 \\
\hline Msus & 2.34 & 1.60 & 3.1 & 2.22 & 1.95 & 9.00 & 3.11 \\
\hline AlKhrubah & 2.21 & 1.86 & 3.1 & 2.06 & 3.39 & 1.01 & 2.00 \\
\hline Samalus & 2.18 & 1.72 & 3.1 & 2.80 & 0.77 & - & 1.86 \\
\hline Qlulud & 2.11 & 2.05 & 3.1 & 1.59 & 3.04 & - & 2.07 \\
\hline Therwa & 2.18 & 2.05 & 3.1 & 1.41 & 1.40 & 6.42 & 2.52 \\
\hline Al Hamamah & 2.31 & 1.90 & 3.0 & 1.58 & 1.97 & 14.22 & 3.89 \\
\hline Tanmlou & 2.30 & 1.57 & 3.2 & 0.35 & - & - & 2.08 \\
\hline Ar Ramlah & 2.36 & 1.50 & 3.0 & 1.58 & 0.66 & 2.40 & 1.83 \\
\hline Muallq & 2.27 & 2.07 & 3.0 & 3.50 & 0.39 & - & 1.91 \\
\hline
\end{tabular}


International Journal of Advances in Scientific Research and Engineering (ijasre), Vol 5 (7), July-2019

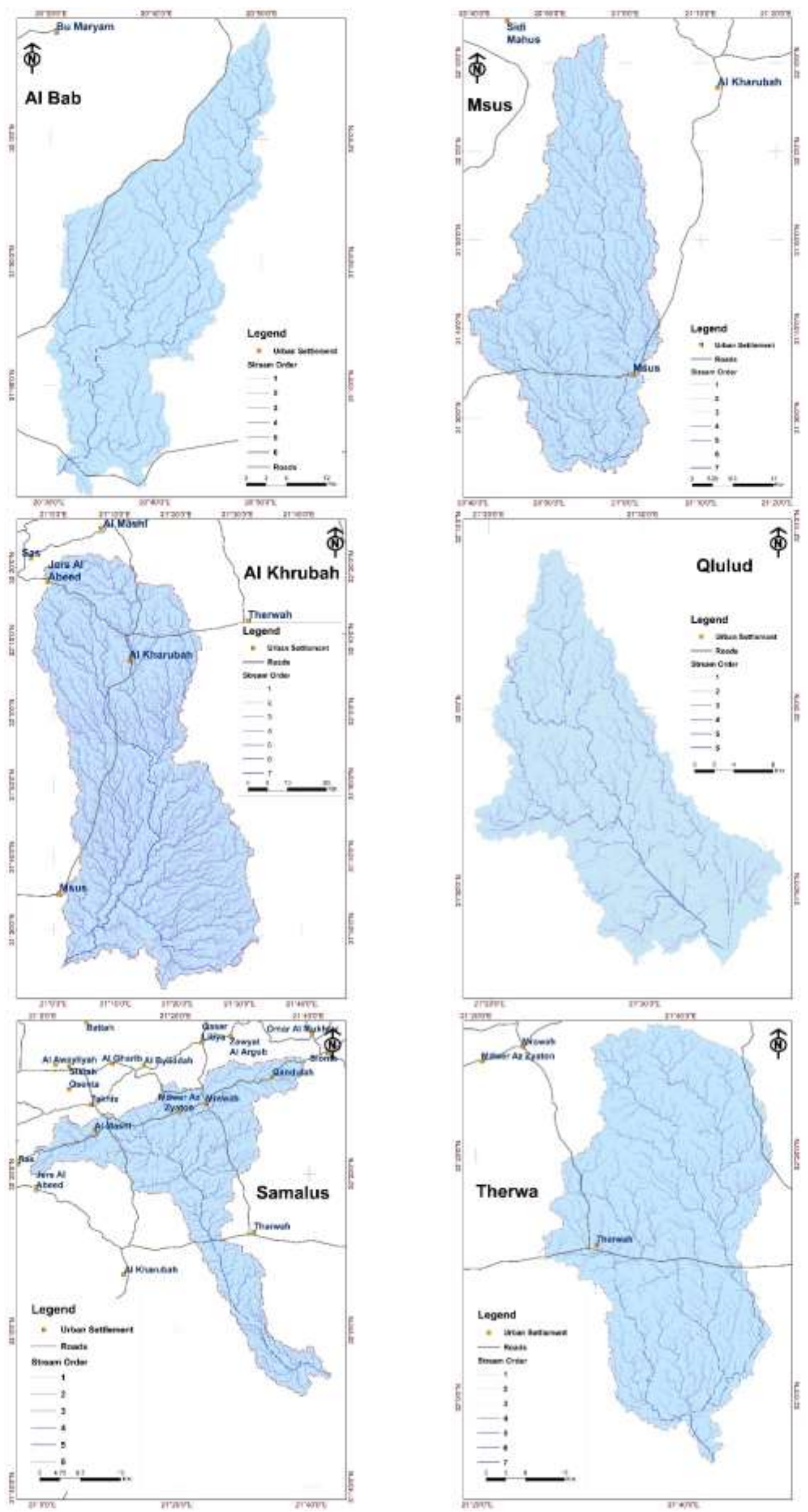

Figure 4. Watersheds stream orders 
International Journal of Advances in Scientific Research and Engineering (ijasre), Vol 5 (7), July-2019
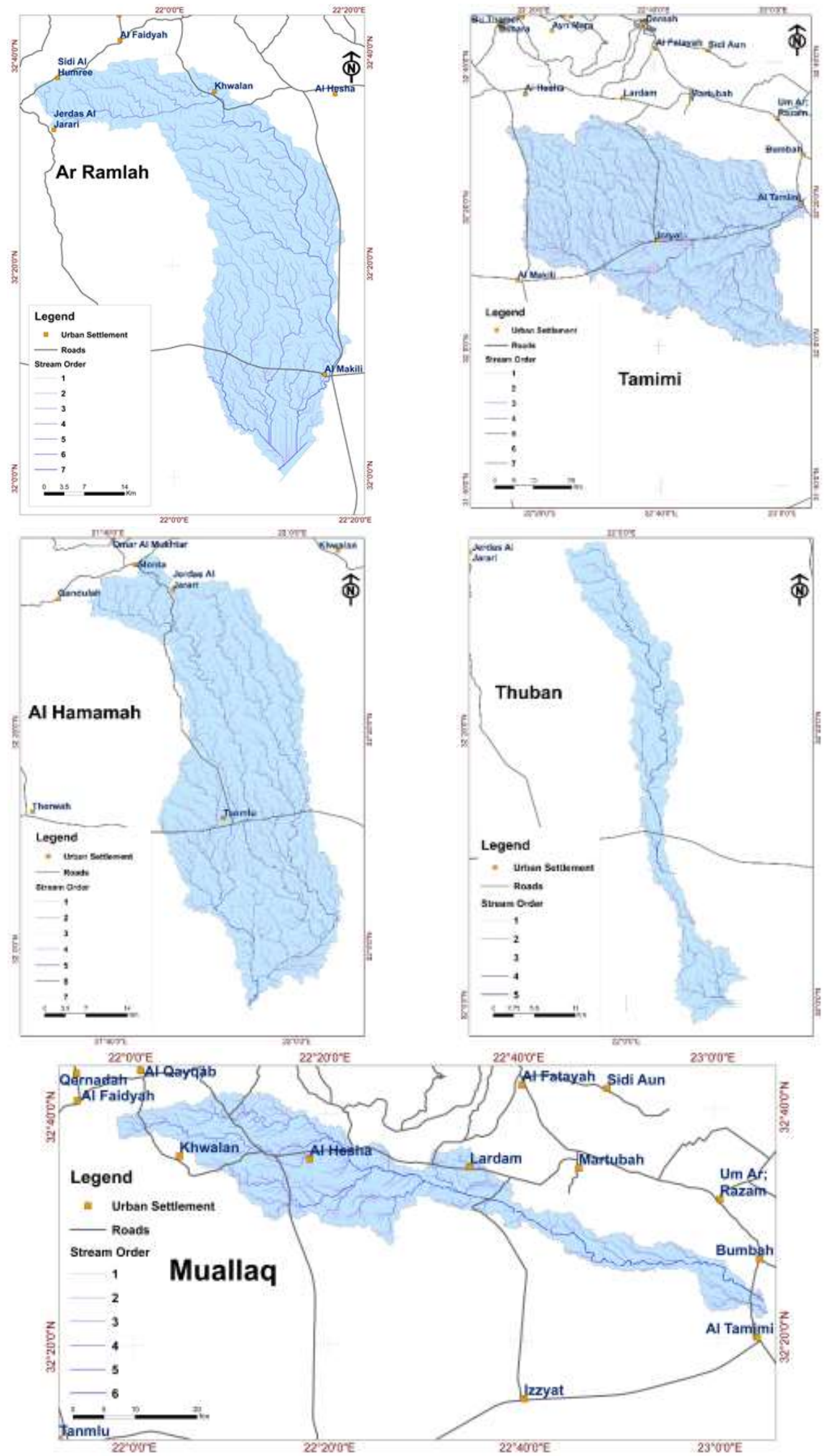

Figure 5. Watersheds stream orders 


\subsection{Areal aspect}

The result of areal aspect computation is shown in table (8) and illustrated in figure (6). Drainage density (Dd) which is total length of streams of all orders per drainage area, also it is important factor for indication of landscape dissection and peak runoff potential of basin [20], where the higher drainage density of the watershed shows poor vegetation cover and impermeable underlying materials and vice versa [21]. The drainage density can be classified according to [20] into; course $\leq 5$, medium 5-10, and fine $\geq 10$ In the study area the drainage density is coarse which indicated the high susceptibility to flooding and soil erosion. The drainage texture (Dt) which is classified into five classes with the following value ranges ; very coarse $(<2)$, coarse $(2-4)$, moderate (4-6), fine (6-8), and very fine (>8) [22]. In the study area most the drainage texture of the watersheds are very coarse with exception of Tamimi, Msus, Al Khrubah, and Qlulud watersheds those are considered as coarse, where hydrologically the very coarse texture watersheds have large basin lag time periods [23]. Stream frequency (Fs) is the total number of channel segments of all stream orders per unit area, and the total number of channel segments are dimension-less[20]. Generally, the value of stream frequency ranges from 3.91 to 9.99. Also, Fs values depend on the lithology of the catchment and reflect the texture of the drainage network. The Fs values are positively correlated with Dd values of the watershed, which means that the increase in stream population is connected to drainage density [24]. High stream frequency means more percolation with respect to drainage density and thus more groundwater potential [12].In the study area, Fs ranges from 2.98 to 3.12 indicating low stream frequency, which can be interpreted as a result of the homogeneity of the underlain strata and low climatic impact. Form factor (Rf) which is the ratio of watershed area to the square of the length of the watershed. Flood hydrograph always affected by the basin form [25]. There are some different value ranges for form factor, as the range values for form factor are $<0.78$ (elongated) and $>0.78$ (circular) [26], also the catchments with high Rf, have peak flows of shorter duration, whereas elongated watersheds with low form factors have lower peak flow of longer duration [27]and[28]. According to the result, the study area watersheds are elongated as its also observed from the values of elongation ratio (Re) and circularity ratio(Rc). Length of Overland (Lof) flow relates to the length of water over the ground before it becomes concentrated into definite steam channels. It is considered the most crucial independent variable affecting hydrological and geomorphological development of drainage basins [29]. The average length of overland flow is relatively half the average distance between stream channels, and thus, is approximately equal to half of the drainage density[5]. Length of overland flow relates inversely to the average channel slope [30]. There are three classes of Lof i.e., low value $(<0.2)$, moderate value $(0.2-0.3)$, and high value $(>0.3)$ [31]. where the low value of Lof indicates high relief [26], short flow paths, more runoff, and less infiltration [31], which leads to more vulnerable to the flash flooding. Meanwhile, a high value of Lof means gentle slopes and long flow paths [32]more infiltration, and reduced runoff [31], in the study area Al Bab watershed has the high value and Tamimi has the low value of Lof, other watersheds can be classified as moderate Lof.

Table 8. Areal aspects

\begin{tabular}{|l|c|c|c|c|c|c|c|c|}
\hline Watershed & $\begin{array}{c}\text { Drainage } \\
\text { Density } \\
\mathbf{k m} / \mathbf{k m}^{\mathbf{2}}\end{array}$ & $\begin{array}{c}\text { Drainage } \\
\text { Texture } \\
\mathbf{k m} / \mathbf{k m}^{\mathbf{2}}\end{array}$ & $\begin{array}{c}\text { Stream } \\
\text { Frequency } \\
\mathbf{1 / S Q} \mathbf{~ k m}\end{array}$ & $\begin{array}{c}\text { Basin } \\
\text { length } \\
\mathbf{k m}\end{array}$ & $\begin{array}{c}\text { Form } \\
\text { Factor }\end{array}$ & $\begin{array}{c}\text { Circularity } \\
\text { Ratio }\end{array}$ & $\begin{array}{c}\text { Elongation } \\
\text { Ratio }\end{array}$ & $\begin{array}{c}\text { Length } \\
\text { of } \\
\text { overland } \\
\text { flow }\end{array}$ \\
\hline Al Bab & 1.420 & 9.690 & 2.980 & 74.100 & 0.197 & 0.123 & 0.501 & 0.352 \\
\hline Msus & 2.000 & 15.180 & 3.100 & 90.900 & 0.247 & 0.148 & 0.561 & 0.250 \\
\hline Al Khrubah & 2.030 & 20.210 & 3.090 & 105.800 & 0.351 & 0.137 & 0.669 & 0.246 \\
\hline Samalus & 1.830 & 9.200 & 3.120 & 87.700 & 0.196 & 0.072 & 0.500 & 0.273 \\
\hline Qlulud & 2.020 & 8.090 & 3.080 & 45.800 & 0.271 & 0.152 & 0.588 & 0.247 \\
\hline Therwa & 1.950 & 14.650 & 3.060 & 67.500 & 0.326 & 0.194 & 0.644 & 0.257 \\
\hline Al Hamamah & 1.910 & 13.380 & 3.120 & 78.900 & 0.244 & 0.152 & 0.558 & 0.261 \\
\hline Thuban & 1.900 & 3.590 & 3.000 & 65.800 & 0.070 & 0.060 & 0.298 & 0.263 \\
\hline Ar Ramlah & 1.920 & 13.490 & 3.160 & 81.700 & 0.234 & 0.147 & 0.545 & 0.261 \\
\hline Muallq & 1.880 & 6.200 & 3.040 & 109.100 & 0.073 & 0.060 & 0.305 & 0.266 \\
\hline Tamimi & 2.530 & 9.690 & 2.980 & 79.900 & 0.448 & 0.149 & 0.755 & 0.197 \\
\hline
\end{tabular}


International Journal of Advances in Scientific Research and Engineering (ijasre), Vol 5 (7), July-2019

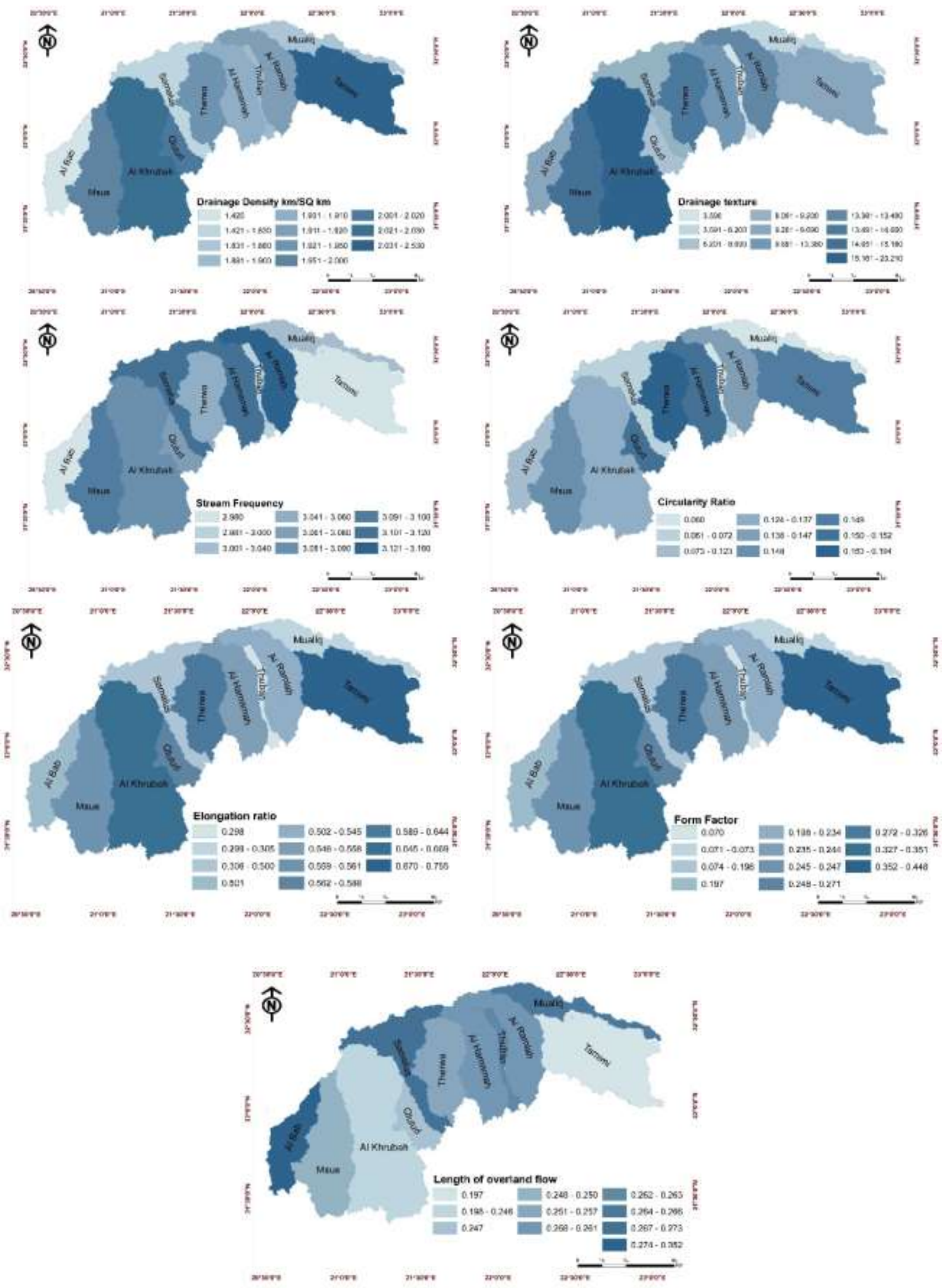

Figure 6. Areal aspect maps 


\subsection{Relief aspect}

The result of relief aspects computation is shown on table (9) and figure (7).Basin relief (Bh) or "total relief" of a watershed is defined as the difference in elevation between the highest and lowest points on the basin [7].The total relief in the study area varies from163 $\mathrm{m}$ in Qlulud watershed and to $858 \mathrm{~m}$ in Muallq, while other watershed basin relief (Bh) shows close values . Relief ratio which is the ratio of the total relief of the basin to it the longest basin length measured along the main drainage line [7]. Where the low value of relief is due to hard rock and low degree of slope. The highest value indicates steep slope and high relief [20].Moreover Relief ratio ( $\mathrm{Rr}$ ) is considered a reasonable mean to measure the overall steepness of a drainage basin. Also, it is an indicator of the intensity of erosion processes operating on the watershed slopes [33],highest relief ration is observed in Muallaq watershed indicating the steep slope, while the low values observed in Qlulud ,Tamimi, and Al Khrubah indicating low slope ,other watersheds observations of ( $\mathrm{Rh}$ ) indicates moderate to low relief. The ruggedness number (Rn) is defined as the product of drainage density ( $\mathrm{Dd})$ and basin relief $(\mathrm{Bh})$ divided by1000 [4] and [6].Observed values of ruggedness number range from low (i.e. 0.06) for smooth and subdued morphology to over 1.0 for sharp morphology, and very high, extreme values (>2) characterizing bad lands topography where the watersheds having high $\mathrm{Rn}$ values can be described by high susceptibility to soil erosion, land sliding, and a high response to an increase in peak discharge[29].I Ruggedness number values in the study area indicates sharp morphology for all the watersheds.

Table 9. Relief aspect

\begin{tabular}{|c|c|c|c|}
\hline Watershed & Basin Relief & Relief ratio & Ruggedness number \\
\hline Al Bab & 505 & 7.28 & 0.72 \\
\hline Msus & 600 & 6.03 & 1.20 \\
\hline Al Khrubah & 607 & 4.22 & 1.23 \\
\hline Samalus & 636 & 7.57 & 1.16 \\
\hline Qlulud & 163 & 3.4 & 0.33 \\
\hline Therwa & 595 & 7.17 & 1.16 \\
\hline Al Hamamah & 708 & 8.43 & 1.36 \\
\hline Thuban & 637 & 19.01 & 1.21 \\
\hline Ar Ramlah & 749 & 8.76 & 1.44 \\
\hline Muallq & 858 & 13.84 & 1.18 \\
\hline Tamimi & 466 & 3.87 & \\
\hline
\end{tabular}

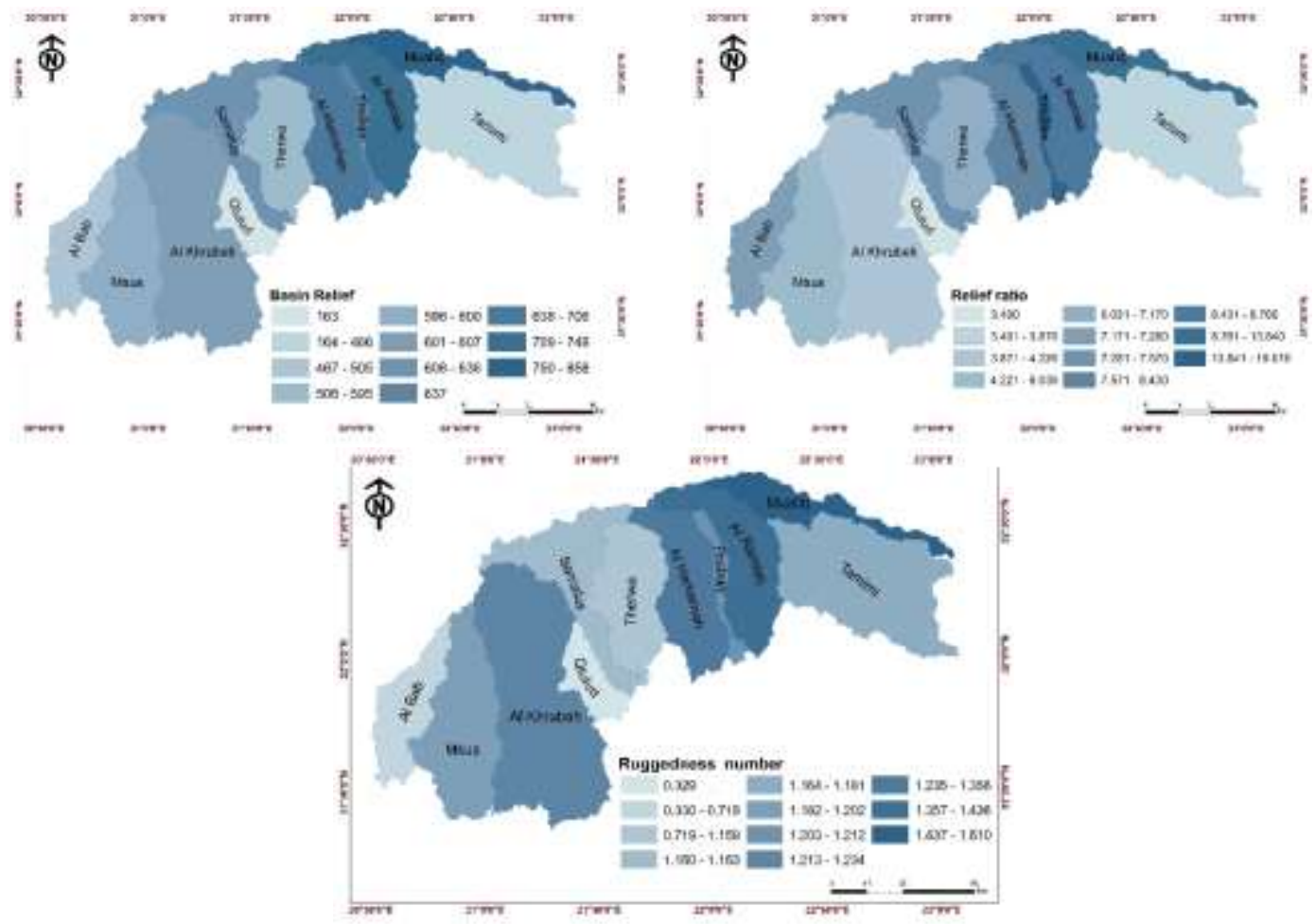

Figure 7. Relief aspect maps 


\section{CONCLUSION}

From the result of morphometric analysis for the 11 watersheds, it is concluded that the whole watersheds area has uniformity in underlying lithology, and there is similarity in the observed morphometric characteristics with some exceptions due to the local geologic structure in some watersheds. Moreover, the watersheds have intermediate to low flooding susceptibility but in case of heavy rainstorms a very strong flash flood may occur, as the drainage networks are coarse with sharp morphology and poor land cover. Also, the watersheds are vital areas for pastoral activities, rainfed crops and considered as promising areas for investment in water harvesting, which in turn covers some of the water demands for different purposes, as well as an important technique in protecting soil from erosion. Moreover, the hydrological investigation is crucially required to quantify the surface runoff of these watersheds which will give more insight for the surface water potential, flood protection procedures, and soil conservations measures.

\section{ACKNOWLEDGMENT}

The author would like to thank Mr A. Arhuma president of the New Libya organization for offering GIS facilities. Also special thanks to Dr.Murad Aburas for his comments those greatly improved the manuscript.

\section{REFERENCES}

1. Asfaw, Daniel, and Getachew Workineh. "Quantitative Analysis of Morphometry on Ribb and Gumara Watersheds: Implications for Soil and Water Conservation.” International Soil and Water Conservation Research, vol. 7, no. 2, 2019, pp. 150-157., doi:10.1016/j.iswcr.2019.02.003.

2. Sukristiyanti, S, et al. "Watershed-Based Morphometric Analysis: A Review." IOP Conference Series: Earth and Environmental Science, vol. 118, 2018, pp. 12-28. doi:10.1088/1755-1315/118/1/012028.

3. Environmental Systems Research Institute (ESRI), “ArcMap.” Deriving Runoff Characteristics-Help | ArcGIS Desktop,2018. http :// desktop.arcgis.com/en/arcmap/10.4/tools/spatial-analyst-toolbox/deriving-runoffcharacteristics.htm. last accessed 28-june-2019

4. A. N. Strahler, Strahler, "Quantitative analysis of watershed geomorphology," Transactions American Geophysical Union, vol. 38, 1957,pp. 913-920.

5. R. E. Horton, "Erosional development of streams and their drainage basins: hydrophysical approach to quantitative morphology," Geological Society of America Bulletin, vol. 56, 1945,pp. 275-370.

6. A. N. Strahler, "Quantitative geomorphology of drainage basins and channel networks," in Handbook of Applied Hydrology, V. T. Chow, Ed., section 4-11, 1964,McGraw-Hill, New York, NY, USA.

7. S. A. Schumms, "Evolution of drainage systems and slopes in Badlands at Perth Amboy,New Jersey," Bulletin of the Geological Society of America, vol. 67, 1956pp,. 597-646

8. Potter, Paul Edwin. "A Quantitative Geomorphic Study of Drainage Basin Characteristics in the Clinch Mountain Area, Virginia and Tennessee. V. C. Miller.” The Journal of Geology, vol. 65, no. 1, 1957, pp. 112-113. DOI:10.1086/626413.

9. Hadley, R. and Schumm, S, "Sediment Sources and Drainage Basin Characteristics in Upper Cheyenne River Basin," US Geological Survey Water-Supply, Paper 153-B, 1961,Washington DC, 198.

10. S. Nitheshnirmal, P. Thilagaraj ,S. Abdul Rahaman ,R. Jegankumar, "Erosion risk assessment through morphometric indices for prioritization of Arjuna watershed using ALOS-PALSAR DEM,” Model. Earth Syst. Environ,2019, pp 1-18. DOI:10.1007/s40808-019-00578-y

11. P. P. Choudhari, Gaurav K. Nigam, Sudhir Kumar Singh \& Sapana Thakur, "Morphometric based prioritization of watershed for groundwater potential of Mula river basin, Maharashtra, India," Geology, Ecology, and Landscapes, vol.2:4, 2018 , pp.256-267.DOI: 10.1080/24749508.2018.1452482

12. Sreedevi, P.D., Sreekanth, P.D., Khan, H.H and Ahmad, S, “ Drainage Morphometry and Its Influence on Hydrology in an Semi-Arid Region: Using SRTM Data and GIS,” Environmental Earth Sciences, vol 70, 2013 ,pp. 839-848. DOI:10.1007/s12665-012-2172-3

13. S. Singh and M. C. Singh, "Morphometric analysis of Kanhar river basin," The National Geographical Journal of India, vol. 43, no. 1, pp. 31-43, 1997.

14. Vinutha D N and Janardhana," Morphometry of the Payaswini Watershed, Coorg District, Karnataka, India, Using Remote Sensing and GIS Techniques," International Journal of Innovative Research in Science, Engineering and Technology, Volume 3, Special Issue 5, Jul 18, 2014. http://www.ijirset.com/upload/2014/special/iciaset/70_vinutha_sm.pdf

15. Doornkamp JC, King CAM ,"Numerical analysis in Geomorphology: An Introduction,” St. Martin's Press, New York. P. 372. 1971. 
16. Nag, Sk. "Morphometric Analysis Using Remote Sensing Techniques in the Chaka Sub-Basin, Purulia District, West Bengal." Journal of the Indian Society of Remote Sensing, vol. 26, no. 1-2, 1998, pp. 69-76., doi:10.1007/bf03007341. Verstappen H, “ Applied geomorphology geomorphological surveys for environmental development,"Elsevier, New York.1983.

17. Thomas J, Joseph S, Thrivikramji K, Abe G, Kannan N,“"Morphometrical analysis of two tropical mountain river basins of contrasting environmental settings, the southern Western Ghats, India Environmental Earth Sciences, vol. 66, no. 8, 2011, pp. 2353-2366., doi:10.1007/s12665-011-1457-2.

18. Shaikh M, Birajdar F ,"Analysis of watershed characteristics using remote sensing and GIS techniques," International Journal of Innovative Research in Science Engineering and Technology vol 4, 2015,pp. 1971-1976., doi:10.15680 /IJIRS ET.2015.04040 23

19. Veeranna, Jatoth et al. " Calculating Linear and Areal and Relief Aspect Parameters Using Geo-Spatial Techniques (ArcGIS 10.2 and SWAT Model) for Akkeru River Basin Warangal, Telangana, India.” International Journal of Current Microbiology and Applied Sciences, vol. 6, no. 10, 2017, pp. 1803-1809., doi:10.20546/ijcmas.2017.610.217.

20. J. M. Harlin and C. Wijeyawickrema, "Irrigation and groundwater depletion in Caddo county, Oklahoma," Journal of the American Water Resources Association, vol. 21, no. 1, 1985, pp. 15-22.

21. Smith, K. G. "Standards for Grading Texture of Erosional Topography." American Journal of Science, vol. 248, no. 9, 1950, pp. 655-668., doi:10.2475/ajs.248.9.655.

22. Angillieri, María Yanina Esper. "Morphometric Analysis of Colangüil River Basin and Flash Flood Hazard, San Juan, Argentina." Environmental Geology, vol. 55, no. 1, 2007, pp. 107-111., doi:10.1007/s00254-007-0969-2.

23. Tucker, Gregory E., and Rafael L. Bras. "Hillslope Processes, Drainage Density, and Landscape Morphology.” Water Resources Research, vol. 34, no. 10, 1998, pp. 2751-2764., doi:10.1029/98wr01474.

24. Vittala, S. Srinivasa, S. and Gowda, H. "Morphometric Analysis of Sub-Watersheds in the Pavagada Area of Tumkur District, South India Using Remote Sensing and GIS Techniques.” Journal of the Indian Society of Remote Sensing, vol. 32, no. 4, 2004, pp. 351-362., doi:10.1007/bf03030860.

25. Vinutha ,D. and R, Janardhana. "Morphometry of the Payaswini Watershed, Coorg District, Karnataka, India, Using Remote Sensing and GIS Techniques." International Journal of Innovative Research in Science, Engineering and Technology, vol. 3, no. 5, 2014, pp. 516-524., doi:10.1007/bf03030860.

26. Youssef, A., Pradhan, B. and Hassan, A. "Flash Flood Risk Estimation along the St. Katherine Road, Southern Sinai, Egypt Using GIS Based Morphometry and Satellite Imagery.” Environmental Earth Sciences, vol. 62, no. 3, 2010 , pp. 611-623., doi:10.1007/s12665-010-0551-1.

27. Baker, Victor R. Flood Geomorphology. Wiley, 1988.

28. Yahya Farhan, Omar Anaba, Ali Salim .2016. "Morphometric Analysis and Flash Floods Assessment for Drainage Basins of the Ras En Naqb Area, South Jordan Using GIS.” Journal of Geoscience and Environment Protection, vol.4 No.6, 2016. pp. 9-33., doi:10.4236/gep.2016.46002.

29. Patel, Dhruvesh P, et al. "Water Harvesting Structure Positioning by Using Geo-Visualization Concept and Prioritization of Mini-Watersheds Through Morphometric Analysis in the Lower Tapi Basin." Journal of the Indian Society of Remote Sensing, vol. 40, no. 2, 2011, pp. 299-312., doi:10.1007/s12524-011-0147-6.

30. Chandrashekar H, Lokesh K V, Sameena M, Roopa J and Ranganna. "GIS -Based Morphometric Analysis of Two Reservoir Catchments of Arkavati River, Ramanagaram District, Karnataka.” International conference on water resources, coastal and ocean engineering Aquatic Procedia, Elsevier (ICWRCOE'15) Edited by G.S. Dwarakish Vol.4.2015, pp.1345 -1353. www.sciencedirect.com/science/article/pii/S2214241X15001765

31. Rai, P. K., Mohan, K., Mishra, S., Ahmad, A., \& Mishra, V. N. A. " GIS- based approach in drainage morphometric analysis of Kanhar River Basin, India.” Applied Water Science, vol.7,2017, pp.217-232., doi:10.1007/s13201-014-0238-y

32. Chopra, R., Dhiman, D. and Sharma, K. Morphometric Analysis of Sub-Watersheds in Gurdaspur District, Punjab Using Remote Sensing and GIS Techniques.” Journal of the Indian Society of Remote Sensing. 33,2005,pp. 531-539. 